\title{
Aleksander Srebrakowski
}

\section{The nationality panorama of Vilnius}

Zarys treści: W artykule przedstawiono podstawowe dane statystyczne ilustrujące zmianę składu narodowościowego Wilna w biegu dziejów. Przedstawiony materiał pozwala odnieść się do kwestii sporu polsko-litewskiego o przynależność państwową tego miasta toczonego po zakończeniu I wojny światowej.

Abstract: This article presents basic statistical data illustrating changes in the nationality composition of Vilnius over the course of history. The discussed material allows us to take a position in the post-First World War Polish-Lithuanian dispute on the state affiliation of the city.

Słowa kluczowe: historia Wilna, skład narodowościowy Wilna, stosunki polsko-litewskie

Keywords: history of Vilnius, nationality composition of Vilnius, Polish-Lithuanian relations

The Polish-Lithuanian dispute over Vilnius, which persisted for almost the entire interbellum, ${ }^{1}$ inflamed the emotions of citizens of both states. The long-lasting discussions and polemics through which the parties attempted to give grounds to their claims and justify the right to incorporate the city within the boundaries of either state ultimately led to distorting the image of the object of dispute. The question that began to be asked was whether Vilnius was Polish or Lithuanian. In this way, the city was stripped of what constituted its peculiar and exceptional character, the considerable variety of intermingling cultures and faiths.

1 The establishment of diplomatic relations, forced by Poland by the ultimatum of 17 March 1938, did not fully resolve this question. The period of normalisation, which lasted for less than eighteen months, was interrupted by the Second World War, during which Polish-Lithuanian antagonisms were rekindled. 
Since 1385, for 410 years, the Crown of the Kingdom of Poland was united to the Grand Duchy of Lithuania (GDL). For the first 184 years, the union was personal; for the next 226 it was real within one single state called the PolishLithuanian Commonwealth. This state of affairs greatly affected the kind of city Vilnius became as the capital of the GDL. When the Act of Kreva was being signed, 62 years had passed since the name of Vilnius had first appeared in historical documents, ${ }^{2}$ the event which we now recognise as the foundation of the city. At that time, it was the residence of the Lithuanian ruler Gediminas. The state he ruled, besides ethnically Lithuanian lands, also included conquered territories of the Rus, and Orthodox Ruthenes then formed a considerable percentage of its population. This share only grew as successive rulers subjugated new tracts of Rus lands. ${ }^{3}$ Except for naming Vilnius as the seat of the Lithuanian ruler, the 1323 document contains no other details about either the appearance or the national/confessional composition of the city's inhabitants. Thanks to archaeological excavations, we know, however, that Vilnius was an important strategic site of the GDL and a pagan cultic centre. ${ }^{4}$ The city itself was probably of no imposing appearance back then. ${ }^{5}$ Only ninety years later, in 1413, during the rule of Jagiełło's cousin Vytautas (Witold), the first description of the Lithuanian capital was penned by the Flemish knight and diplomat Gilbert de Lannoy. In contrast with Novogrod the Great, which he had visited earlier and by which he was greatly impressed, ${ }^{6}$ he described Vilnius as a narrow, unwalled strip of land huddled around a high hill bearing a wood and stone castle, with the majority of buildings consisting of chaotically strewn wooden houses and only some contemporary churches erected

${ }^{2}$ Skarbiec diplomatów papiezkich, cesarskich, krolewskich, książęcych; uchwat narodowych, postanowień różnych władz i urzędów posługujących do krytycznego wyjaśnienia dziejów Litwy, Rusi Litewskiej i ościennych im krajów, vol. 1, assembly and commentary by I. Daniłowicz, Wilno, 1860, pp. $155-156$.

3 Determining the exact proportions of Ruthenian and Lithuanian populations in early GDL times is difficult. Older literature used to affirm that the Ruthenes were a group that dominated the state. This position later began to be revised. Jan Jakubowski even declared that in the early sixteenth century the Lithuanians accounted for more than 50\% of GDL inhabitants. The critical research of Henryk Łowmiański led him to determine that they constituted no more than 25\% of GDL inhabitants at that time. This data is, however, applicable to the entire population, but when only the gentry is taken into account, it appears that the Lithuanians had a $60 \%$ share of it. For more on this, see: H. Łowmiański, Studia nad dziejami Wielkiego Księstwa Litewskiego, Poznań, 1983, pp. 389-393; M. Liedke, Od prawosławia do katolicyzmu. Ruscy możni i szlachta Wielkiego Księstwa Litewskiego wobec wyznań reformacyjnych, Białystok, 2004, pp. 31-36.

${ }^{4}$ N. Kitkauskas, A. Lisanka, "Nauji duomenys apie viduramžių Vilniaus katedrą," Kultūros Barai, 1986, no. 4, pp. 59-63, no. 5, pp. 56-61, no. 6, pp. 47-51, no. 7, pp. 58-61; N. Kitkauskas, A. Lisanka, "Perkūno šventyklos liekanos Vilniaus Žemutinejje pilyje," Kultūros Barai, 1986, no. 12, pp. 51-55; N. Kitkauskas, A. Lisanka, S. Lasavickas, "Perkūno šventyklos liekanos Vilniaus Žemutinèje pilyje,” Kultūros Barai, 1987, no. 1, pp. 40-63, no. 2, pp. 53-57.

${ }^{5}$ H. Mościcki, Wilno, Warszawa, 1922, p. 7; A.R. Čaplinskas, Vilniaus istorija legendos ir tikrove, Vilnius, 2010, p. 12.

${ }^{6}$ J. Lelewel, Gilbert de Lannoy i jego podróże, Poznań, 1844, pp. 31 and 33. 
in stone. ${ }^{7}$ Thus, even though Vilnius emerged as the central hub ${ }^{8}$ of an extensive state, it was only on the first stage of its urban development and looked nothing like a medieval European metropolis. On its inhabitants, Gilbert de Lannoy wrote nothing. Further on, however, he described Trakai, a city located some 30 kilometres to the west. According to his rather laconic account, we know it was inhabited by Tatars, Germans, Lithuanians, Ruthenes and Jews. ${ }^{9}$ It should, therefore, be assumed that a similar mix of nationalities was also present in Vilnius, especially since, as mentioned above, the GDL was a multi-ethnic state with a considerable share of Ruthenian population. ${ }^{10}$ Moreover, according to contemporary custom, to retain the possession of subjugated territories, the Lithuanian rulers and their family members often married Ruthenian princes and princesses, thus falling within the orbit of Christian (Orthodox) culture. We know, for example, that the wives of Gediminas' son, Duke Algirdas, ${ }^{11}$ patronised two Orthodox churches built around the mid-fourteenth century in Vilnius. ${ }^{12}$ Moreover, the city already had a Ruthenian quarter (civitas ruthenica). ${ }^{13}$ The name appears in Wigand's chronicle when mentioning the burning of the Ruthenian quarter of Vilnius (ut civitatem ruthenicam incinerarent) by the Teutonic Knights in $1383 .{ }^{14}$ In the 1470 s, a considerable political role in Vilnius was also played by the German population, whose presence can still be traced in the sixteenth century and beyond. ${ }^{15}$ In old documents, the city quarter inhabited by Catholics was dubbed the "German Town." ${ }^{16}$ As regards the Jews, we have a traditional but undocumented account that the first Jewish cemetery in Vilnius was founded in 1487, although the earliest documentary mentions of the presence of a Jewish community in the city date only from $1568 .{ }^{17}$

7 Ibid., pp. 39 and 41.

${ }^{8}$ Magdeburg law was bestowed on Vilnius on 22 March 1387.

9 J. Lelewel, op. cit, p. 43.

10 Russian historiography uses the term Литовская Русь, or Lithuanian Rus, meaning lands conquered by the Lithuanians while the GDL was being formed.

11 The first was Anna (Maria?) of Vitebsk, and the other Uliana of Tver. For more, see: J. Tęgowski, Pierwsze pokolenie Giedyminowiczów, Poznań-Wrocław, 1999, pp. 48-57.

12 A. Radziukiewicz, Na wschód od zachodu, Białystok, 2008, p. 189.

13 V. Drèma, Dingęs Vilnius, Vilnius, 1991, p. 18; K. Katalynas, Vilniaus pletra XIV-XVII a., Vilnius, 2006, pp. 151 and 155.

${ }^{14}$ Puścizna po Janie Długoszu dziejopisie polskim to jest: Kronika Wiganda z Marburga rycerza i kapłana zakonu krzyżackiego na wezwanie Długosza z rymowanej kroniki niemieckiej na język łaciński przetłomaczona, transl. E. Raczyński, Poznań, 1842, pp. 294-295.

15 Э. Гудавичюс, История Литвы с древнейщих времен до 1569 года, vol. 1, Москва, 2005, p. 92; W. Semkowicz, "Hanul, namiestnik wileński (1382-1387) i jego ród," Ateneum Wileńskie, 1-2, 1930, pp. 1-20; Г. Саганович, “Вильна в описании немецкого путешественника Самуэля Кихеля (1586 г.),” in: Senosios raštijos ir tautosakos squveika: kultūrine Lietuvos Didžiosios Kunigaikštystès patirtis, Vilnius, 1998, pp. 193-197.

${ }^{16}$ K. Katalynas, loc. cit.

17 I. Cohen, Vilna, Philadelphia, 1943, pp. 2-3; E. Meilus, "The history of Vilnius old Jewish cemetery at Šnipiškès in the period of the Grand Duchy of Lithuania," Lithuanian Historical Studies, 12, 2007, p. 65 . 
In turn, the first Pskov Annals, while describing the Vilnius fire of 1471, mention the "Lach end" or Polish quarter. ${ }^{18}$ From these examples, it is evident that ever since its early documented history, the city was a melting pot of nations, cultures and religions ruled by Lithuanian dukes. ${ }^{19}$ Such a state of affairs imprinted a multi-national character on Vilnius culture from the very start, except that, as regards language (i.e. writings), the share of Lithuanian was minimal. This was because when the GDL was formed the Lithuanians had not yet devised a written language, and their entire literary culture from the early statehood times was exclusively oral, limited to popular songs (the dainos), proverbs, puzzles, or fairy tales. ${ }^{20}$ The earliest preserved Lithuanian documents were actually written in Church Slavonic, Ruthenian, ${ }^{21}$ Latin, Polish, German, Hebrew, later Yiddish, and even in some cases Greek. ${ }^{22}$

The union between Lithuania and Poland caused Polish to gradually supplant the formerly dominant Ruthenian in GDL administration over time, and in 1696, it ultimately replaced its predecessor. ${ }^{23}$ Moreover, the Lithuanian boyars (gentry) were eager to absorb that language, which eventually resulted in the Lithuanian political elites being completely Polonised. In his monograph on Aleksander Jagiellon, ${ }^{24}$ Fryderyk Papée, considering what language dominated at the court of that ruler ${ }^{25}$ around 170 years after Vilnius was first mentioned in documents, concluded that it was indeed Polish. Further, Papée also declared that no evidence could be found to prove that Aleksander knew Lithuanian. ${ }^{26}$ Therefore, as even the court of the Grand Duke spoke predominantly in Polish, the boyars could not fail to be influenced. It must, however, be remembered that the voluntary Polonisation of Lithuanian boyars was their rational, conscious political choice, because by converting to Catholicism and integrating with Polish gentry they improved their material standing and acquired a number of political privileges which they lacked when they were ruled by the Grand Duke. Among such privileges was the right

18 Полное собраніе русскихъ лютописей изданное по Высочайщему Повелюнію Археографическою Коммссіею, vol. 4, Петербург, 1848, p. 239.

19 For more about the multi-cultural character of Vilnius, see: J. Niedźwiedź, Kultura literacka Wilna (1323-1655), Kraków, 2012; A. Ragauskas, Vilniaus miesto valdantysis elitas. XVII a. antroje puseje (1662-1702 m.), Vilnius, 2002, pp. 279-299.

${ }^{20}$ M. Jackiewicz, Dzieje literatury litewskiej do 1917 roku, Warszawa, 2003, p. 21. Z. Stoberski, Historia literatury litewskiej. Zarys, Wrocław-Warszawa-Kraków-Gdańsk-Łódź, 1986, pp. 7-17.

${ }^{21}$ The literature also uses appellations such as "Old Belarusian" or "Chancery Slavic." Cf. M. Jackiewicz, Dzieje literatury litewskiej do 1917 roku, Warszawa, 2003, p. 28.

22 J. Niedźwiedź, op. cit., p. 38; M. Jackiewicz, op. cit., pp. 27-32.

${ }^{23}$ M. Ostrówka, "Polszczyzna w Wielkim Księstwie Litewskim. Aspekt arealny i historyczny," in: Kultura i języki Wielkiego Księstwa Litewskiego, ed. M.T. Lizisowa, Kraków, 2005, p. 1004.

${ }^{24}$ F. Papée, Aleksander Jagiellończyk, Kraków, 1999, pp. 33-34.

${ }^{25}$ His wife was Helena, daughter of Grand Duke of Moscow Ivan III Vasilyevich.

${ }^{26}$ In historiography, the predominant view is that the last Grand Duke of Lithuania who spoke Lithuanian was Casimir Jagellon, Aleksander's father. 
to freely administer their patrimony or the possibility of continued use of the estates by boyars' widows after the death of their husbands. ${ }^{27}$ The Lithuanian historian Darius Staliūnas favours the argument that material advantages were the main factor urging Lithuanians to enter into close relations with Poland. This attitude persisted even in the nineteenth century: in 1861, shortly before the outbreak of the January Uprising, demonstrations and petitions to Tsarist authorities demanded the incorporation of GDL lands into the Kingdom of Poland. ${ }^{28}$ It appears, however, that Russian historian Matvey Lubavski was closer to the truth when he affirmed that the Lithuanian gentry chose the path to constitutionalism and political democracy instead of absolutism and centralised administration towards which the GDL political system might have leaned. ${ }^{29}$ Obviously, the privileges and freedoms they won at that time later resulted in material benefits.

Mentioning the process of Polonisation in GDL lands, it must be added that it affected not only Lithuanian gentry but also other inhabitants; for example, German burghers in Vilnius. ${ }^{30}$ It also applied to countryside dwellers from the Vilnius region. Linguists note that Vilnius was located on the Lithuanian-Russian ethnic frontier, which was receding towards Lithuania under Slavic (Ruthenian) influence. This facilitated the subsequent Polonisation of the rural population that was influenced by Polonised Lithuanian gentry. ${ }^{31}$ This process, actually already initiated when the city was founded, led to imprinting a Polish character on it over the course of centuries. Obviously, this refers to linguistic character, especially as regards written language, ${ }^{32}$ because politically the Lithuanian gentry, and specifically mostly the great landowners, tried to emphasise their independence and distinctiveness until the end of the Polish Commonwealth. Despite this, when modern nations started to appear in the nineteenth century, the issue of language influenced the choice of nation by inhabitants of Lithuanian lands, who had already been immersed in Polish language and culture for a few hundred years. The majority of Lithuanian gentry, Polonised a few generations earlier, but also members of other social classes, usually began to identify with Poles when forced to choose which

27 M. Liedke, op. cit., p. 37.

${ }^{28}$ D. Staliūnas, "Konserwatywna szlachta litewska w połowie XIX w. - Kwestia podwójnej świadomości politycznej," in: Kultura Litwy i Polski w dziejach. Tożsamość i wspótistnienie, Kraków, 2000, p. 143.

29 М.К. Любавскій, Очеркъ исторіи Литовско-Русскаго государства до Люблинской уніи включительно, Москва, 1915, pp. 2-3.

${ }^{30}$ G. Schramm, "Protestantismus und städtische Gesellschaft in Wilna (16. - 17. Jahrhundert)," Jahrbücher für Geschichte Osteuropas, vol. 17, 1969, p. 188.

${ }^{31}$ M. Kowalski, “Wileńszczyzna jako problem geopolityczny w XX wieku," in: Problematyka geopolityczna ziem polskich, ed. P. Eberhardt, Warszawa, 2008, pp. 269-272.

32 As cited by Maria Barbara Topolska, from 1553 to 1660, 44.5\% of materials printed in the GDL were in Polish, $37 \%$ in Latin and $12.5 \%$ in languages that use Cyrillic script. Cf. M.B. Topolska, Społeczeństwo i kultura $w$ Wielkim księstwie Litewskim od XV do XVIII wieku, Poznań-Zielona Góra, 2002, p. 169. 
nation to belong to. The foundation of these choices, in addition to other factors, might have been the condition of the Lithuanian revival movement and the values it stood for. Actually, apart from a few members of the gentry, a decided majority of its adherents were recruited from young Lithuanian intelligentsia of peasant origin. Moreover, the movement was aimed mostly at the peasant population, which was not to the liking of many a scion of nobility. The fact that a uniform literary Lithuanian language was still being intensely developed at the time (in the nineteenth century) was probably also of quite some significance. ${ }^{33}$ This led many to view the entire enterprise as something artificial or, even worse, inspired by the enemies of Poland. It was this very thinking that became the cornerstone of later Polish-Lithuanian conflict. Wiktor Sukiennicki ascribed this state of affairs to the Polish Commonwealth failing to develop at an opportune time a term equivalent to "Briton," which was used to describe all inhabitants of the United Kingdom of Great Britain and Ireland. ${ }^{34}$ In the Commonwealth, the words "Poland" and "Poles" persisted as such general terms. It is difficult to conclude whether introducing an appellation such as "Commonwealthian," which could be applied in equal measure to Poles, Lithuanians and Ruthenes, might have defused the future LithuanianPolish conflict. The fact remains, however, that already in the nineteenth century Lithuanian gentry and intelligentsia were viewed as Poles. It was these circumstances that led Adam Mickiewicz to pen the following passage in The Books and the Pilgrimage of the Polish Nation: "The Lithuanian and the Masovian are brothers, and do brothers quarrel, because one is named Wladislaw, and the other Witowt? Their common name is the same - that of Poles." 35 It should be clearly noted, however, that this question relates to the sphere of feelings of those who use such appellations, and not to the terminology then in use. Browsing through Polish press from the late nineteenth and early twentieth century, we can see that Vilnius is referred to mostly as "the capital of Gediminas," or possibly "the capital of Lithuania," where Lithuanians dwelt. However, the context of the articles clearly shows that it is Poland and Poles that are described in these terms. This was because Lithuania was then overwhelmingly viewed as a region of Poland, and the Lithuanians as its inhabitants. All of this was the result of assigning the name of Poland to the entire Commonwealth; in speaking about Poland, it was inferred to refer to the Commonwealth.

${ }^{33}$ Jan Otrębski, an expert on Lithuanian, notes the fact that a literary language common to all Lithuanians took shape only between 1880 and 1900. Quoted from: J. Otrębski, Gramatyka języka litewskiego. vol. 1: Wiadomości wstępne. Nauka o głoskach, Warszawa, 1958, pp. 55-56.

34 W. Sukiennicki, "Polityczne konsekwencje błędu semantycznego," Zeszyty Historyczne, 72, 1985, pp. 18-33.

35 A. Mickiewicz, Ksiegi narodu polskiego i pielgrzymstwa polskiego, Paris, 1832, p. 72 [transl. J. Ridgway, London, 1833, p. 55]. 
Before we proceed to present the detailed ethnic composition of Vilnius from the late nineteenth century onwards, let us first consider the changes in the city's population as a whole. Thanks to preserved materials compiled by the municipal authorities, we can trace these processes since the end of the eighteenth century. Moreover, to make our picture more complete, we also have estimates from the first half of the sixteenth and mid-seventeenth centuries.

Table 1. Changes in the number of Vilnius inhabitants from 1530 to 2011 (in thousands) ${ }^{36}$

\begin{tabular}{|c|c|}
\hline Year & Number of inhabitants \\
\hline 1530 & 30.0 \\
\hline 1654 & 14.0 \\
\hline 1795 & 17.7 \\
\hline 1796 & 17.5 \\
\hline 1800 & 31.0 \\
\hline 1811 & 56.3 \\
\hline 1818 & 33.6 \\
\hline 1834 & 52.3 \\
\hline 1861 & 60.5 \\
\hline 1869 & 64.4 \\
\hline 1880 & 89.6 \\
\hline 1886 & 103.0 \\
\hline 1897 & 154.5 \\
\hline 1900 & 162.6 \\
\hline 1914 & 214.6 \\
\hline 1917 & 138.8 \\
\hline 1919 & 129.0 \\
\hline
\end{tabular}

36 Sources of data: Lietuvos Centrinis Valstybès Archyvas, F. R-743, Ap. 5, B. 45, 1. 23; International migration in Lithuania. Causes, consequences, strategy, ed. A. Sipavičienè, Vilnius, 1997, p. 318; Первая всеобщая перепись населения Российской империи, 1897 г. IV. Виленская губерния, fasc. 2, Санкт-Петербург, 1901, pp. 88-89; Spis ludności na terenach administrowanych przez zarząd Cywilny Ziem wschodnich (grudzień 1919), ed. E. Romer, Lwów, 1920, p. 27; Rocznik Statystyczny Wilna 1936, Wilno, 1938, p. 9; Итоги Всесоюзной переписи населения 1979 года по Литовской СССР, vol. 1, Вильнюс, 1980, p. 228; Vilniaus miesto savivaldybès gyventojai ir būstai, Vilnius, 2004, p. 38; M. Łowmiańska, Wilno przed najazdem moskiewskim 1655 roku, Wilno, 1929, pp. 74-77. 


\begin{tabular}{|c|c|}
\hline Year & Number of inhabitants \\
\hline 1923 & 167.5 \\
\hline 1931 & 195.1 \\
\hline 1939 & 215.2 \\
\hline 1941 & 186.3 \\
\hline 1942 & 143.5 \\
\hline 1945 & 110.0 \\
\hline 1946 & 123.6 \\
\hline 1959 & 236.1 \\
\hline 1970 & 372.1 \\
\hline 1979 & 475.8 \\
\hline 1989 & 576.7 \\
\hline 1993 & 590.1 \\
\hline 1994 & 578.6 \\
\hline 2001 & 553.9 \\
\hline 2011 & 535.6 \\
\hline
\end{tabular}

Going through this list, we can easily recognise the disasters that struck the city from the early sixteenth century onwards. The first was the Polish-Russian war of 1654-1667, followed by the Napoleonic Wars with the campaign of 1812, the First World War and Polish-Soviet War, and the Second World War. All these events had a major impact on the temporary decrease of the city's population, and hence changes in the national composition, because the number of those who died and departed was uneven among each nationality.

In its early period, when Vilnius was the capital of GDL and the seat of the Grand Duke, it naturally attracted, on one hand, the boyars (gentry), who wanted to remain as close to the ruler as possible; and on the other hand, experts of various kinds who could offer their services to those people. This, in turn, resulted in a systematic growth of the city population. With its 30,000 inhabitants in 1530, Vilnius could not hold a candle to the European metropolises of the time such as Paris, with a population of 185,000 around 1500 , Venice with 110,000, Genoa with 150,000, or Florence with 60,000. Compared to other Polish cities, however, Vilnius was doing much better, its population second only to Kraków, and coming ahead of Lwów, Poznań, and especially Warsaw, whose dynamic expansion would not take place until later. Unfortunately, the seventeenth and eighteenth centuries brought a slow decline of the city, as it was ravaged by plagues, fires and wars. 
When the Union of Lublin was signed, the political importance of Vilnius dwindled, because Polish kings now automatically became Grand Dukes of Lithuania and there was no separate grand ducal court in the city. In the nineteenth century, despite rebuilding that followed the events of 1812, the city's relevance reached new lows, especially after the January Uprising, when it was demoted to a provincial locality, the capital of a governorate in the Russian Empire. Interestingly, despite the lack of major industries, the suppression of the university in 1832, and the underused possibilities of becoming an agricultural trade hub, the number of the city's inhabitants regularly grew and was not considerably different from the cities we compared it to above based on early sixteenth-century data. The geographical and statistical atlas published by A. F. Marks in 1908 cites the following figures, showing the number ${ }^{37}$ of inhabitants of cities to which we compared Vilnius earlier: Vilnius 165,000, Genoa 235,000, Florence 210,000, Venice 152,000, Kraków 104,000, Poznań 140,000 and Lwów 180,000. ${ }^{38}$ Thanks to the development of major industries and trade, cities that decidedly overtook Vilnius in population included Warsaw $(760,000)$ and Łódź $(350,000)$, which at that time ranked third and fifth in the entire Russian Empire. ${ }^{39}$ On the same list, Vilnius came ninth. In the northwestern corner of the Russian Empire, Vilnius was the second-largest city after Riga with 280,000 inhabitants. For comparison, Minsk had 91,000, and Reval (Tallin), Dvinsk (Daugavpils) and Białystok 66,000 each. ${ }^{40}$ It is therefore apparent that despite a considerable economic and cultural decline, Vilnius still remained a notable urban centre, which, according to classifications used in Poland today, could be ranked among large cities.

The exact statistical national composition of Vilnius can be determined only from the late nineteenth century onwards, when the Russian authorities conducted the first empire-wide population census. Beginning with 1897, population censuses were conducted reasonably systematically, organised by those who held the authority over the city at that time - Russians, Germans, Poles, Germans again, USSR authorities and finally Lithuanians. In the eighteenth and for the majority of the nineteenth century different kinds of statistical research were conducted in Vilnius, not specifically to examine the national composition of the city ${ }^{41}$ but

\footnotetext{
37 The atlas contains no information about the year or provenance of its statistical details.

38 Всеобщій геограбическій и статистическій карманный атласъ, Санкт-Петербург, 1908, $3^{\text {rd }}$ edition, pp. 23, 31, 39 and 43.

39 Ibid., p. 43.

40 Ibid.

${ }^{41}$ While a population census was held in 1789 in the Commonwealth, Irena Gieysztorowa notes that it cannot be termed a universal census, because it did not encompass the tax-exempt classes (i.e. the gentry and clergy). The list of census columns also did not provide for registering confession or nationality. Cf.: I. Gieysztorowa, "Państwowy spis ludności w 1789 r.," in: Pierwszy
} 
mostly as a result of its economic circumstances. The data collected in them was, however, used by various authors to make an estimate of the national composition of the Vilnius population. In 1929, Maria Łowmiańska of the Vilnius Stefan Bathory University compiled an estimate of the local confessional and national composition in the mid-eighteenth century. ${ }^{42}$ According to her findings, the city, which then had 14,000 inhabitants, was dominated by its Catholic population. The next largest group were the Uniates, followed by Protestant and Orthodox communities, whose sizes were about equal. The Jewish population at that time consisted of some 1,500. The list was rounded out by the Mohammedans, who reportedly numbered a few hundred. ${ }^{43}$ The author also found that "the Catholic population of Vilnius is generally (in linguistic and cultural terms) Polish, with a few percent of Germans and Lithuanians; the Uniates and Disuniates, formerly Ruthenes, are now dominated by Poles. Likewise, the Orthodox and Protestants are mostly of Polish origin." 44

In 1832, Michał Baliński compiled a statistical work dealing with the Vilnius population, yet he admitted that he was able to divide it only in terms of social class and confessions. It is worthwhile to cite the words with which he began to discuss the issue: "As to their descent, the inhabitants of Vilnius are Lithuanians, Russians, Germans and Jews. The numbers of other races are so small that they cannot form a division of their own in this respect." ${ }^{45}$ In the context of the issue under consideration, it is interesting that he does not mention Poles, although the Polish language was then dominant in the city. The prime evidence that Polish was the lingua franca for Vilnius inhabitants is the fact that Kuryer Litewski, the first newspaper printed there in 1760, was in Polish. Moreover, even during the partitions, until 2 January 1834, when this title started to appear in Polish and Russian, ${ }^{46}$ all periodicals issued in the city were Polish publications. ${ }^{47}$ Entirely Russian newspapers did not start to appear in Vilnius until 1834, Belarusian until 1862, Jewish until 1841 (in Hebrew) and until 1896 (in Yiddish), and Lithuanian until 1904. ${ }^{48}$ Let us go back to Baliński's book, however, where the author's calculations show that in $1832,57.5 \%$ of Vilnius' inhabitants were Jews. Later, he slightly overestimates the total number of inhabitants, but also the number of Jews,

spis domów i ludności Rzeczypospolitej Polskiej 1789 r. Wybrane pisma historyczno-demograficzne, ed. M. Latuch, Warszawa, 2005, p. 128.

${ }^{42}$ M. Łowmiańska, Wilno przed najazdem moskiewskim 1655 roku, Wilno, 1929, p. 78.

43 Ibid., p. 91.

${ }^{44}$ Ibid.

${ }^{45}$ M. Baliński, Opisanie statystyczne miasta Wilna, Wilno, 1835, p. 61.

46 "Programma na wydawanie od 1834 roku urzędowey gazety Kuryer Litewski," Kuryer Litewski, no. 154 of 29 December 1833, p. 19.

47 J. Kazlauskaitè, Vilniaus periodiniai leidiniai 1760-1918. Bibliografinè rodyklè, Vilnius, 1988, pp. 96-103; "Dziennikarstwo polskie na Litwie," Kuryer Litewski, no. 1 of 1 (14) September 1905, pp. 3-4.

${ }^{48}$ J. Kazlauskaite, loc. cit. 
increasing the percentage to $60 \%$. It should be remarked, however, that Baliński did not have data about the Orthodox, Mohammedans and Karaites, and accordingly the percentage of Jews should be cut down (by how much?); however, this does not change the fact that in these times the Jews must have formed the relative majority of the city's inhabitants, surpassing the number of Catholics. ${ }^{49}$ The trend noted by Baliński remained constant almost until the outbreak of the First World War. According to data of the Russian military administration, in 1848 Jews accounted for more than one half of the city's inhabitants. ${ }^{50}$ In 1858, Adam Honory Kirkor, using data collected in 1853 by a committee on statistics from various religious and social institutions, found that the number of Vilnius inhabitants was 61,185 . Among these, the most numerous uniform groups were adherents to the Mosaic religion, numbering 28,555, followed by Catholics, mostly Poles and Lithuanians (26,540), the Orthodox (4,930), Protestants (866) and Mohammedans (285). ${ }^{51}$ From these figures it appears that in 1853 the Jewish population formed $46.7 \%$ of city inhabitants. A similar percentage of Jews might also be calculated based on the figures given by Baliński if the missing data about the Orthodox, Mohammedans and Karaites were supplied.

In subsequent years, 1869 and 1872, other censuses were organised in Vilnius, but these activities were still related to fiscal matters. It was not until 1875 that the North-Western Branch of the Russian Geographic Society carried out a one-day census of the city population. The total number of Vilnius inhabitants was then reckoned at $82,668 .{ }^{52}$ Broken down by confession, the figures are:

$\begin{array}{ll}37,909 & (\mathbf{4 5 . 9 \% )} \text { Jews } \\ 27,781 & (\mathbf{3 3 . 6 \% )} \text { Catholics } \\ 13,093 & \mathbf{( 1 5 . 8 \% )} \text { Orthodox } \\ 2,402 & (\mathbf{2 . 9 \% )} \text { Lutherans and Calvinists } \\ 573 & (\mathbf{0 . 7 \% )} \text { Old Believers } \\ 260 & \mathbf{( 0 . 3 \% )} \text { Mohammedans } \\ 85 & (\mathbf{0 . 1 \% )} \text { Karaites } \\ 6 & (\mathbf{0 . 0 \% )} \text { Armenians } \\ 559 & (\mathbf{0 . 7 \% )} \text { no confession given. }\end{array}$

49 Slightly earlier, in 1830, Ignacy Chodźko estimated the number of Vilnius inhabitants at 50,000, of which 30,000 (60\%) were to be Jews. Cited after: Материаль для географии и статистики России, собранные обицерами Генерального итаба. Виленская губерния, еd. А. Корева, Санкт-Петербург, 1861, р. 711.

50 Военно-статистическое обозрение Российской Империи, vol. 9, pt. 2: Виленская губерния, Санкт-Петербург, 1848, p. 31.

51 A.H. Kirkor, "Ludność miasta Wilna," Teka Wileńska, 3, 1858, p. 205.

52 Вильна и окрестности. Путеводитель и историческая справочная книжка, Вильна, 1883, p. 305. 
It is also worthwhile noting that according to the cited census, $50.3 \%$ of the city's inhabitants were illiterate. ${ }^{53}$ This suggests that these people's national self-identification might be doubtful if an attempt was then made to conduct a census registering the ethnic origin of the inhabitants. This also offered numerous opportunities for census takers to manipulate the figures. For the nineteenth-century Vilnius, this issue requires detailed research before the results can be used in scholarly publications. Six years later, in 1881, according to data collected by the governorate's committee on statistics from fiscal authorities and the police, Vilnius had a total of 89,557 inhabitants. Broken down by confession, the figures are:
45,624
(50.9\%) Jews
32,769
(36.6\%) Catholics
8,365
(9.4\%) Orthodox
1,896
(2.1\%) Lutherans and Calvinists
558
(0.6\%) Old Believers
250
(0.3\%) Mohammedans
95
$\left(\mathbf{0 . 1 \% )}\right.$ Karaites. $^{54}$

Despite different origins, these figures concurrently show that during the partitions Vilnius became a city dominated by the Jewish population. The cause of this turn of events was the Russian policy towards the nation, as since the times of Catherine II steps had been taken to promote its rapid assimilation. One of the methods used was depriving Jews of land. As a result, they became unable to support themselves in the countryside and sought a living in the cities, Vilnius among them. ${ }^{55}$ Another instrument devised to further assimilation was developing a profiled network of state schools for Jews. Initially, these were elementary-grade schools, while in 1847 two state rabbinic schools were established in Zhytomyr and Vilnius, ${ }^{56}$ the latter one existing until 1873. The fact that the school was located in Vilnius confirms the importance of the former GDL capital as a centre of Jewish culture.

Mentioning the dominant position of Jews in nineteenth-century Vilnius, it must be remembered that this community in the former areas of the Commonwealth was notable for its low degree of assimilation. Moreover, in the cities themselves they actually lived apart from the rest of the population, with whom they inter-

53 Ibid.

${ }^{54}$ Ibid., p. 306.

${ }^{55}$ For a wider treatment, see: I. Schiper, “Żydzi na kresach północnych i wschodnich w czasach porozbiorowych," in: Żydzi w Polsce odrodzonej. Działalność społeczna, gospodarcza, oświatowa i kulturalna, ed. I. Schiper, A. Tartakower, A. Hafftka, Warszawa, n.d., pp. 563-574.

${ }^{56}$ For a wider treatment, see: V. Dohrn, "Das Rabbinerseminar in Wilna (1847-1873). Zur Geschichte der ersten staatlichen höheren Schule für Juden im Russischen Reich," Jahrbücher für Geschichte Osteuropas, vol. 45, 1997, pp. 379-400. 
acted only when engaging in trade and services. Further integration was also hindered by the limited representation of the Jewish community in the municipal self-government authorities.

As already noted above, the first universal census in which Vilnius was included took place in 1897. Subsequent censuses took place in 1915, 1916, 1919, 1923, 1931, 1941, 1942, 1951, 1959, 1970, 1979, 1989, 2001 and 2011. The 1897 census was conducted by the Russian government, and the 1915 and 1916 ones by the German occupation authorities. The 1919, 1923 and 1931 censuses were carried out by the Poles. During the Second World War, the 1941 and 1942 censuses were organised by Germans, and censuses between 1951 and 1989 were taken by the USSR authorities. Finally, the 2001 and 2011 censuses are already the work of independent Lithuania. In addition to census results, we also have the findings of the interbellum Central Statistical Office of Vilnius City published in the Vilnius Statistical Yearbook. It included data on the confessions of city inhabitants since 1869 , based on former Russian publications. ${ }^{57}$ Because it is mostly data on the number of Poles we are interested in, the fact that the censuses were held by various parties who exercised authority in the Vilnius region at the time dismisses the allegation of using one-sided sources favourable only to Poland.

While earlier on, only fragmentary data about the confessional composition of Vilnius were given, now we can present its changes from 1869 to 1931 in a systematic way. The terminal years have been decided by available source materials. 1869 is the earliest date mentioned in the Vilnius Statistical Yearbook. 1931, in turn, is the date of the second and last population census carried out in the Second Polish Republic. The German censuses of 1941 and 1942, and the Soviet censuses do not mention the confession of inhabitants; therefore, we are limiting our review to the year 1931 .

As already noted above, it can be seen that the Mosaic faith dominated in the city until the outbreak of the First World War. However, in the late nineteenth century, and specifically in the universal census, the Jewish population for the first time showed a downward trend. During the two years from 1895 to 1897 the number of Jews living in Vilnius decreased by 13,144 . On the other hand, the number of Catholics and Orthodox continued to grow, causing the gap between Judaism and Christianity, especially Catholics, to narrow. In 1895, Jews in Vilnius outnumbered Catholics by 31,125, while in 1897 the difference was only 7,143. According to German data from the First World War, the percentages of population by confession were as follows: Catholics $54.1 \%$, Jews $43.5 \%$, Orthodox $1.5 \%$, Lutherans $0.8 \%$ and others $0.1 \%$. In 1916, the adherents of Judaism thus became

57 This was a series of publications issued between 1845 and 1915: Памятная книжка Виленской губернии. 
Table 2. The confessional composition of Vilnius from 1869 to $1931^{58}$

\begin{tabular}{|c|c|c|c|c|c|c|c|c|}
\hline \multirow[b]{2}{*}{ Year } & \multirow{2}{*}{ 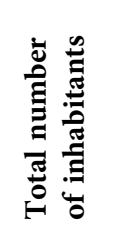 } & \multicolumn{7}{|c|}{ Number of inhabitants by confession: } \\
\hline & & 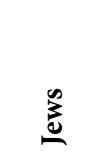 & 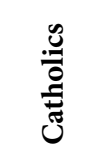 & 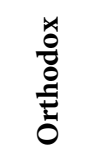 & 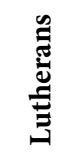 & 串 & 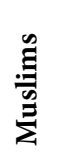 & $\frac{0}{\dot{\omega}}$ \\
\hline 1869 & 64,377 & 30,733 & 22,804 & 8,435 & 1,711 & 57 & 106 & 531 \\
\hline 1872 & 76,356 & 37,697 & 27,664 & 8,369 & 1,791 & 58 & 140 & 637 \\
\hline 1880 & 89,636 & 45,198 & 33,144 & 8,491 & 1,940 & 82 & 246 & 535 \\
\hline 1890 & 109,808 & 59,198 & 33,628 & 13,787 & 1,962 & 127 & 360 & 746 \\
\hline 1897 & 154,532 & 63,831 & 56,688 & 28,638 & 2,233 & 155 & 842 & 2,145 \\
\hline 1916 & 140,840 & 61,233 & 76,196 & 2,049 & 1,158 & & & 204 \\
\hline 1919 & 128,954 & 46,559 & 75,336 & 5,873 & & & & 1,186 \\
\hline 1923 & 167,454 & 55,437 & & & & & & 112,017 \\
\hline 1931 & 195,071 & 55,006 & 125,999 & 9,321 & & & & 4,745 \\
\hline
\end{tabular}

Note: Except for 1919 and 1931, in all other years the number of inhabitants includes temporary visitors.

the second-largest confessional group in the city. Now, it was the Catholics who outnumbered them by 14,963 . Following the end of the First World War, when the Polish-Soviet war had been raging for several months, the decline of the Jewish population numbers continued. In 1919, the gap between the two groups grew to 28,777 in favour of the Catholics. Following the great upheavals of 1914-1920, in times of peace the Jewish community in Vilnius started to grow again. From 1919 and 1923, its size increased by 8,878 . In turn, by the 1931 universal census it fell by 431 , a minor decrease. It can therefore be considered that the Jewish population at that time remained basically unchanged, in contrast to Catholics, whose numbers systematically grew. Ultimately, then, eight years before the outbreak of the Second World War the confessional composition of the inhabitants was Catholics $64.6 \%$, Jews $28.2 \%$, Orthodox $4.8 \%$ and other confessions $2.4 \%$.

Now let us review the changes in the national composition of Vilnius. This time, our data range spans the period from 1897 to 2011. Due to the varied level of detail of the published data, we have limited ourselves to citing figures for the four main nationalities living in Vilnius (Jews, Poles, Russians and Lithuanians),

58 Data sources: Первая всеобщая перепись населения Российской империи, 1897 г. IV. Виленская губерния, fasc. 2, Санкт-Петербург, 1901, pp. 88-89; Rocznik Statystyczny Wilna 1936, Wilno, 1938, p. 9; M. Brensztejn, Spisy ludności m. Wilna za okupacji niemieckiej od d. 1 listopada 1915, Warszawa, 1919, p. 21; Spis ludności na terenach administrowanych przez zarząd Cywilny Ziem wschodnich (grudzień 1919), ed. E. Romer, Lwów, 1920, p. 27; Drugi powszechny spis ludności $z$ dn. 9 XII 1931 r. Mieszkania i gospodarstwa domowe. Ludność. Stosunki zawodowe. Miasto Wilno, Warszawa, 1937, p. 11. 
while lumping the remainder under "others." It must also be remembered that in the 1897 and 1931 censuses the inhabitants were not asked about nationality, but their first language, which was not fully aligned with nationality, because, for example, some Jews chose Polish or Russian instead of Hebrew or Yiddish.

Table 3. National composition of Vilnius from 1897 to $2011^{59}$

\begin{tabular}{|c|c|c|c|c|c|c|}
\hline \multirow{2}{*}{$\begin{array}{c}\text { Census } \\
\text { year }\end{array}$} & \multirow{2}{*}{$\begin{array}{l}\text { Total number } \\
\text { of inhabitants }\end{array}$} & \multicolumn{5}{|c|}{ Number of inhabitants by nationality } \\
\hline & & Jews & Poles & Russians & Lithuanians & Others \\
\hline \multirow{2}{*}{1897} & \multirow{2}{*}{154,532} & 61,844 & 47,641 & 30,919 & 3,124 & 11,004 \\
\hline & & $40.0 \%$ & $30.8 \%$ & $20.0 \%$ & $2.0 \%$ & $7.2 \%$ \\
\hline \multirow{2}{*}{1916} & \multirow{2}{*}{140,840} & 61,265 & 70,629 & 2,030 & 3,699 & 3,217 \\
\hline & & $43.5 \%$ & $50.2 \%$ & $1.4 \%$ & $2.6 \%$ & $2.3 \%$ \\
\hline \multirow{2}{*}{1919} & \multirow{2}{*}{128,954} & 46,559 & 72,416 & $\bullet$ & 2,920 & 7,059 \\
\hline & & $36.1 \%$ & $56.1 \%$ & $\bullet$ & $2.3 \%$ & $5.5 \%$ \\
\hline \multirow{2}{*}{1923} & \multirow{2}{*}{167,454} & 56,168 & 100,830 & 4,669 & 1,445 & 4,342 \\
\hline & & $33.5 \%$ & $60.2 \%$ & $2.8 \%$ & $0.9 \%$ & $2.6 \%$ \\
\hline \multirow{2}{*}{1931} & \multirow{2}{*}{195,071} & 54,596 & 128,628 & 7,372 & 1,579 & 2,896 \\
\hline & & $28.0 \%$ & $65.9 \%$ & $3.8 \%$ & $0.8 \%$ & $1.5 \%$ \\
\hline \multirow{2}{*}{1941} & \multirow{2}{*}{186,313} & 30,179 & 94,511 & 6,712 & 52,370 & 2,541 \\
\hline & & $16.2 \%$ & $50.7 \%$ & $3.6 \%$ & $28.1 \%$ & $1.4 \%$ \\
\hline \multirow{2}{*}{1942} & \multirow{2}{*}{143,498} & $\bullet$ & 103,203 & 6,012 & 29,480 & 4,793 \\
\hline & & $\bullet$ & $71.9 \%$ & $4.2 \%$ & $20.6 \%$ & $3.3 \%$ \\
\hline \multirow{2}{*}{1951} & \multirow{2}{*}{179,300} & 5,500 & 37,700 & 59,700 & 55,300 & 21,100 \\
\hline & & $3.1 \%$ & $21.0 \%$ & $33.3 \%$ & $30.8 \%$ & $11.8 \%$ \\
\hline \multirow{2}{*}{1959} & \multirow{2}{*}{236,078} & 16,354 & 47,226 & 69,416 & 79,363 & 23,719 \\
\hline & & $6.9 \%$ & $20.0 \%$ & $29.4 \%$ & $33.6 \%$ & $10.1 \%$ \\
\hline \multirow{2}{*}{1970} & \multirow{2}{*}{372,100} & 16,491 & 68,261 & 91,004 & 159,156 & 37,188 \\
\hline & & $4.4 \%$ & $18.3 \%$ & $24.5 \%$ & $42.8 \%$ & $10.0 \%$ \\
\hline
\end{tabular}

59 Sources: Lietuvos Centrinis Valstybės Archyvas, F. R-743, Ap. 5, B. 45, 1. 23; Первая всеобщая перепись населения Российской империи, 1897 г. IV. Виленская губерния, fasc. 2, СанктПетербург, 1901, pp. 88-89; M. Brensztejn, Spisy ludności m. Wilna za okupacji niemieckiej od d. 1 listopada 1915, Warszawa, 1919, p. 21; Spis ludności na terenach administrowanych przez zarząd Cywilny Ziem wschodnich (grudzień 1919), ed. E. Romer, Lwów, 1920, p. 27; Итогu Всесоюзной переписи населения 1970 года по Литовской СССР, Вильнюс, 1975, р. 297; Итоги Всесоюзной переписи населения 1979 года по Литовской СССР, vol. 1, Вильнюс, 1980, p. 228; 1989 metu visuotinio gyventojų surašymo duomenys, vol. I, Vilnius, 1991, p. 25; P. Gaučas, M. Karalienè, "Dabartines Vilniaus gyventojų nacionalines sudeties kitimo tendencijos," Geografija, 17, 1981, p. 143; Vilniaus miesto savivaldybès gyventojai ir büstai, Vilnius, 2004, p. 38; Lietuvos gyventojai 2011 metais. 2011 m. gyventoju surašymo rezultatai, Vilnius, 2012, p. 23. 


\begin{tabular}{|c|c|c|c|c|c|c|}
\hline \multirow{2}{*}{$\begin{array}{c}\text { Census } \\
\text { year }\end{array}$} & \multirow{2}{*}{$\begin{array}{l}\text { Total number } \\
\text { of inhabitants }\end{array}$} & \multicolumn{5}{|c|}{ Number of inhabitants by nationality } \\
\hline & & Jews & Poles & Russians & Lithuanians & Others \\
\hline \multirow{2}{*}{1979} & \multirow{2}{*}{475,825} & 10,723 & 85,562 & 105,618 & 225,137 & 48,785 \\
\hline & & $2.3 \%$ & $18.0 \%$ & $22.2 \%$ & $47.3 \%$ & $10.2 \%$ \\
\hline \multirow{2}{*}{1989} & \multirow{2}{*}{576,747} & 9,109 & 108,239 & 116,618 & 291,527 & 51,254 \\
\hline & & $1.6 \%$ & $18.8 \%$ & $20.2 \%$ & $50.5 \%$ & $8.9 \%$ \\
\hline \multirow{2}{*}{2001} & \multirow{2}{*}{553,904} & 2,785 & 104,446 & 77,698 & 318,510 & 50,465 \\
\hline & & $0.5 \%$ & $18.9 \%$ & $14.0 \%$ & $57.5 \%$ & $9.1 \%$ \\
\hline \multirow{2}{*}{2011} & \multirow{2}{*}{535,631} & $\bullet$ & 88,379 & 64,275 & 338,520 & 44,457 \\
\hline & & $\bullet$ & $16.5 \%$ & $12.0 \%$ & $63.2 \%$ & $8.3 \%$ \\
\hline
\end{tabular}

Note: In the 2011 census results, nationalities were given as percentages; the figures in the table result from recalculating the percentage data as absolute values.

Observing the changes in the national composition of Vilnius over 114 years, we can see that in the last decade of the nineteenth century the city was still dominated by the Jewish population, which formed a relative majority (40\%) of its inhabitants. However, a change was already taking place during the First World War. In 1916, the absolute numbers of the Jewish population stayed basically at the 1897 level, only decreasing by 579 . The number of Poles, on the other hand, rose significantly, by as much as 22,988 . At the same time, a considerable decrease in those who named Russian as their first language (by 28,889) and those classified as "others" (by 7,787) was noted, resulting in a total loss of 36,676. Yet between 1897 and 1916, the city's population decreased by only 13,692 . Thus, after subtracting those two sums, we get 22,984 persons who were still staying in the city but were recorded as Russians or "others" in the earlier census. As we can see, this number is basically identical to the demonstrated increase of the Polish population in 1916. The difference between the results is just four people.

The sudden increase in the number of Poles registered in Vilnius at the expense of Russians and "others" is, despite appearances, not surprising at all. It should first be remarked that Polish authors have long noted the biased nature of the 1897 Russian census in which, they believed, a large proportion of the Poles living in areas incorporated directly into Russia were classified as Russians. ${ }^{60}$ In turn, comparing these figures with the city's confessional data, we can see that the number of Catholics, which here comprised mainly Poles, Lithuanians and Belarusians, systematically grew. In 1894 and 1895, the number rose by 10,559, between 1895

${ }^{60}$ Cf. J. Czekanowski, Stosunki narodowościowo-wyznaniowe na Litwie i Rusi w świetle źródeł oficjalnych, Lwów, 1918, pp. 8-13.; O. Czarnowski, "Metoda historyczna obliczenia liczebności ludności polskiej zamieszkałej na terytorium dawnej Litwy i Rusi pod zaborem rosyjskim," in: Pamiętnik VI Powszechnego Zjazdu Historyków Polskich w Wilnie 17-20 września 1935 r., vol. 1: Referaty, ed. F. Pohorecki, Lwów, 1935, p. 232. 
and 1897 by another 10,838 , and from 1897 to 1916 by yet another 19,508 . We must note that the first two, five-digit increases in the number of Catholics, Poles among them, took place in a single year and then in two years. On the other hand, the last increase, by almost 20,000, was spread over a period of 19 years, meaning that the tendency shown in previous years was slowed down. Besides this, two events that took place in the region we are discussing should be mentioned. First, the 1905 Revolution bolstered the democratic tendencies in the Russian empire, among them abolishing the suppression of the Polish language. If speaking Polish in public was previously prohibited, Poles could now not only use their language in administration but also once again publish Polish language periodicals or establish a network of Polish schools. This obviously strengthened the Polish element in the region. In turn, the 1915 German occupation of some lands of the former GDL forced Russian military men and officials to leave Vilnius, and those who previously opportunistically concealed their Polishness now felt emboldened to declare it. The subcutaneous Polish character of Vilnius, mentioned by authors of the accounts of the city cited above, now had ideal conditions to burgeon.

The results of the 1916 German census are of prime importance with respect to Polish-Lithuanian relations, because it showed that Poles (50.2\%) were the dominant nationality in Vilnius, followed by Jews (43.5\%), Lithuanians $(2.6 \%)$, Russians (1.4\%), Belarusians (1.4\%) and others (0.9\%). ${ }^{61}$ It were these nationality figures of the Vilnius population that moved Poles to make an attempt to incorporate the city within the borders of the renascent Polish state. The crucial argument they offered was that the Poles formed an absolute majority in the city while the Lithuanians were a decided minority, less than three percent strong. The Lithuanian side tried to refute this conclusion in various ways. During the most acute phase of the Polish-Lithuanian conflict, it was frequently asserted that Poles living in Lithuania were but Polonised Lithuanians who stuck to Polishness only because they were supported by the Warsaw government. ${ }^{62}$ Noted Lithuanian essayist Andrius Rondomanskis (Andrzej Rondomański) offered a vivid depiction of this process, using a botanical metaphor: "This is, by the way, the natural end of plants sown on foreign soil and forced to grown there against nature. Only local and national species can hope to thrive and flourish in the normal way. This anticipated decline of Polishness in non-Polish lands will align perfectly with the regular fiasco of denationalisation policy everywhere and at all times [...]." ${ }^{33} \mathrm{In}$ turn, another author hiding behind the initials I. R. published a curious pamphlet around 1920 in which he argued that the blood flowing in the veins of descendants

${ }^{61}$ M. Brensztejn, Spisy ludności m. Wilna za okupacji niemieckiej od d. 1 listopada 1915, Warszawa, 1919, p. 21.

62 This argument was later reiterated in publications of foreign authors. Cf. for example: E. Hurwicz, Der neue Osten. Waldungen und Ausichten, Berlin, 1927, p. 78.

63 A. Rondomański, "Polskość w Litwie i jej przyszłość," in: id., Litewska krew, Wilno, 1921, p. 5. The entire article is included in the annex. 
of Poles who had arrived in Lithuania in the sixteenth century was now four-fifths Lithuanian. ${ }^{64}$ Perhaps in 1921 such a view could have convinced some readers, but the results of subsequent censuses strongly undermine this kind of thinking. It is, of course, known, as noted above, that the ancestors of many Poles living in today's Lithuania were Polonised Lithuanian gentry, and in some cases also Polonised urban and rural dwellers. The process of Polonisation, however, lasted for hundreds of years, and led to the awakening of Polish national consciousness, which at the time of these censuses was very deeply rooted in the majority of Vilnius Poles. The best proof are the results of subsequent censuses of the city's population. We are not speaking here about the 1919, 1923 and 1931 ones, since they will always be disputed by the Lithuanian side as biased, but those conducted by the Germans, Soviets and Lithuanians themselves. During the Second World War, Poles retained their position as the most populous nation in the city. In 1942, when the Germans were exterminating the local Jews, and accordingly omitted them when taking the census, the percentage of the Polish population reached 71.9\%, the highest ever. Following the end of the war, between 1944 and 1947, 171,168 Poles and Jews eligible to leave were evacuated ${ }^{65}$ from the Lithuanian SSR. A total of 90,630 left the Vilnius evacuation region that covered the city and its environs. ${ }^{66}$ Hence, when another census was taken in 1951, the number of Poles shown to live in Vilnius fell to 37,700 , or $21 \%$. At that time, Russians accounted for $33.3 \%$, a relative majority, and Lithuanians for $30.8 \%$ of the population. Yet over the subsequent decades until 1989, Polish numbers in Vilnius systematically grew, ultimately reaching 108,239 . Since 1991, in independent Lithuania, a slow decline of that community commenced. Today, the number of Poles stands at 88,379 . The recent decrease is, however, caused by migration to Western Europe, which started when Lithuania joined the European Union. As it appears from the above, it would be difficult to explain the existence of the still numerous and aware Polish diaspora in Vilnius by the mere skin-deep Polonisation of the Lithuanian population. Even though 76 years have passed since the Vilnius region fell away from Poland, the Poles continue to feel Polish and stress this at every opportunity. Yet if the view of early twentieth-century Lithuanian journalists and politicians were correct, the "swindled" Lithuanian population would long ago have gone back to its non-Polish roots, becoming fully assimilated to the Lithuanian majority instead of persisting in its Polishness. It should, therefore, be concluded that

${ }^{64}$ I.R., Kwestia polsko-litewska w chwili obecnej, Wilno, n.d. [probably 1920], pp. 7-16. Cited after: J. Jurkiewicz, Rozwój polskiej myśli politycznej na Litwie i Białorusi w latach 1905-1922, Poznań, 1983, p. 240.

65 To this very day, the media use the erroneous term "repatriation," which literally means returning to one's fatherland. However, in official documents signed by the Polish and Soviet sides it was referred to as "evacuation." This is the name I use here, as it describes this operation more adequately.

66 A. Srebrakowski, Polacy w Litewskiej SRR 1944-1989, Toruń, 2001, p. 98. 
the drive of Vilnius inhabitants towards Poland after the end of the First World War was a natural process and not a clever hoax of Polish politicians.

The early twentieth-century Polish domination in Vilnius is also evidenced by data of another kind. In 1913, the Vilnius estimation committee compiled a list of real estate found in the city. According to its findings, the list contained 5,653 buildings (both residential and others) of various kind, owned by: Poles $-2,745$ (48.6\%); Jews - 1,547 (21.4\%); Russians - 751 (13.3\%); Lithuanians - 55 (1.0\%); other nationalities - $162(\mathbf{2 . 9 \% )}$, the government, clergy and social institutions $393(\mathbf{6 . 8 \%}) .{ }^{67}$ These figures thus provide additional evidence that during the dispute over the national allegiance of Vilnius, Polish was the nationality which dominated in the city and naturally was the main party that could and would actually decide its future following the end of the First World War.

As for the Lithuanian population of Vilnius, its position in the interbellum was quite marginal, at least in terms of numbers, not political and cultural activity. According to Polish data, these numbers initially reached almost 3,000 but later fell by almost a half. In turn, Lithuanian estimates declared that some six to seven thousand Lithuanians lived in the city. ${ }^{68}$ Even if these estimates were considered more trustworthy than Polish ones, at 7,000 the percentage of the Lithuanians in Vilnius would be 5.4\% in 1919 and 3.4\% in 1931, anyway. On the other hand, if the number of Poles was decreased by 4,000 , or the amount by which the number of Lithuanians was increased compared to Polish census data, it turns out that they constituted 53.1\% of city inhabitants in 1919 and 63.9\% in 1931, still an absolute majority, their numbers exceeding those of the Lithuanians 9.8 times in 1919 and 18 times in 1931. For comparison, in the post-war period the Lithuanians were 1.5 times more numerous than Poles in 1951, 2.7 times in 1989 and 3.8 times in 2011, not reaching even half the numerical superiority which the latter held in 1919. Moreover, the Lithuanians did not become an absolute majority among the city's inhabitants until 1989 and did not reach the 1931 percentage of Poles until $2011 .^{69}$ This, in turn, means that the Lithuanians did not and do not have a suitable population base around Vilnius which could be used to quickly increase the number of inhabitants of Lithuanian nationality, as was the case with the Poles.

Analysing the almost 700 years of Vilnius history, we can see it first as a Lithuanian capital built by the Lithuanians on the frontier between pagan and

${ }^{67}$ K. Niedziałkowski, "Biedne miasto. (Trochę cyfr ze statystyki Wilna)," Przegląd Wileński, no. 22-23 of 8 (21) June 1913, p. 8.

68 B. Makowski, Litwini w Polsce 1920-1939, Warszawa, 1986, p. 30.

${ }^{69}$ Another interesting trend should also be remarked upon. Despite the intense drive of Lithuanians to migrate to the West since 2004, the 2011 census showed that Lithuanian numbers in Vilnius steadily grew, and that those of other nationalities greatly declined. The number of Lithuanians did, of course, decrease nationwide, but not in Vilnius. 
Christian (Catholic and Orthodox) lands, where members of different nations and cultures lived together since the city's foundation. When Lithuania decided to enter into a political alliance (personal union) with Poland, the city quickly became the main centre of Western culture in the Ruthenian borderlands. Until the downfall of the Commonwealth, Vilnius still retained its character as a Lithuanian capital, but already before the Union of Lublin the Polish language and culture slowly began to predominate. The city's inhabitants, however, described themselves as Lithuanians, although the meaning of this term varied over time. In the twilight period of the Commonwealth, it began to be applied more to a region than a state, while the Commonwealth itself began to be called Poland abroad. ${ }^{70}$ The nineteenth century, when Vilnius, together with the rest of Lithuanian lands, was incorporated into the Russian Empire, brought about important changes in the make-up of nationalities in the city. First, the Jewish population began to form the relative majority of inhabitants. At the same time, because with the rise nationalism the inhabitants were almost forced to opt for a specific nationality, most Polish-speaking Lithuanians started to unequivocally declare themselves as Poles. Saying sum gente Lithuanus natione Polonus ${ }^{71}$ was no longer enough: one had to clearly make a choice between Poland or Lithuania. In such cases, most inhabitants of Vilnius and its environs opted for Polishness. This had specific consequences in the form of a desire of these inhabitants to join other Poles in a single state. In the interbellum period, even though the city was still inhabited by different nationalities, Poles were the strongly dominating element. However, the situation changed after the Second World War. As the Jews were killed and Poles, especially the intelligentsia, left Vilnius after the war, a vacuum formed, which was filled mostly by migrating Russians and Lithuanians. However, the city also began to attract the neighbouring rural population. Due to the lack of greater numbers of Polish intelligentsia, the Poles, while systematically growing in

${ }^{70}$ In the last years of the Commonwealth, there were, however, attempts to use the name of Poland (as the Polish Republic) as a de facto standard. The constitution of 3 May 1791 was to employ this name to describe the entire Polish-Lithuanian state, yet ultimately the name was not adopted. However, the Reciprocal Guarantee of Two Nations of 20 October 1791 contains the following words: "having always in mind our duties towards our common fatherland, the Polish Republic..." However, the ultimate tone of the document speaks in favour of continuing the Republic as a two-nation state. For a wider treatment, see: J. Malec, "Charakterystyka prawnoustrojowa unii polsko-litewskiej w latach 1569-1795," in: O nowy kształt Europy: XX-wieczne koncepcje federalistyczne w Europie Środkowo-Wschodniej i ich implikacje dla dyskusji o przyszłości Europy, ed. J. Kłoczowski, S. Łukasiewicz, Lublin, 2003, pp. 19-35; U. Agustyniak, Historia Polski 1572-1795, Warszawa, 2008, pp. 32; For the text of the Reciprocal Guarantee... see: Akta unji Polski z Litwq 1385-1791, ed. S. Kutrzeba, W. Semkowicz, Kraków, 1932, pp. 398-399.

${ }^{71}$ Among Lithuanian activists, the supporter of this position was bishop Antanas Baranauskas. For more on this, see: P. Łossowski, "Dwie drogi odrodzenia kulturalnego i narodowego Litwinów: Baranauskas i Basanavičius," Studia z Dziejów Rosji i Europy Środkowo-Wschodniej, 31, 1996, pp. 149-155. 
numbers, for a long time no longer played the role they could have done. Today, the decided majority of inhabitants of the Lithuanian capital are Lithuanians, who imprint a specific national character on the city. The dream of the late nineteenth-century national Lithuanian revival leaders has therefore been realised, and the Lithuanians finally have a Lithuanian capital for their national state. And yet, the considerable percentage of other nationalities (36.8\%) cultivates the multi-cultural legacy of the city.

\section{Abstract}

Vilnius, the former capital of the Grand Duchy of Lithuania (GDL) is located at the junction of the Lithuanian and Belarusian ethnic areas. From its very foundation, the city had an ethnically mixed population. In addition to Lithuanians and Ruthenes, the ancestors of today's Belarusians, it was also inhabited by Germans, Jews and Poles, and later by Tatars, Karaites, Russians and other nationalities. Already during medieval times, when the Polish-Lithuanian union was established, the gradual process of Polonising the city and its environs had begun. Especially after the Union of Lublin, the Polish language became dominant in the GDL capital. In the nineteenth century, with the rise of nationalism, when the inhabitants began to be asked to declare their nationality, Poles and Jews constituted a decided majority of the residents. Shortly before the outbreak of the First World War, Poles started to form an absolute majority in the city, and this state of affairs persisted after the end of the Second World War. In the post-war period, the number of Lithuanians in Vilnius grew slowly but steadily, reaching an absolute majority in 1989 .

\section{Bibliography}

\section{Archival records}

Lietuvos Centrinis Valstybès Archyvas, F. R-743, Ap. 5, B. 45.

\section{Source editions}

Akta unji Polski z Litwa 1385-1791, ed. S. Kutrzeba, W. Semkowicz, Kraków, 1932.

Lelewel J., Gilbert de Lannoy i jego podróże, Poznań, 1844.

Puścizna po Janie Długoszu dziejopisie polskim to jest: Kronika Wiganda z Marburga rycerza i kapłana zakonu krzyżackiego na wezwanie Długosza z rymowanej kroniki niemieckiej na język łaciński przetłomaczona, transl. E. Raczyński, Poznań, 1842.

Skarbiec diplomatów papiezkich, cesarskich, krolewskich, ksiązęcych; uchwał narodowych, postanowień różnych władz i urzędów posługujących do krytycznego wyjaśnienia dziejów Litwy, Rusi Litewskiej i ościennych im krajów, vol. 1, assembly and commentary by I. Daniłowicz, Wilno, 1860.

Полное собраніе русскихъ лютописей изданное по Высочайшему Повелюнію Археографическою Коммссіею, vol. 4, Петербург, 1848. 


\section{Statistical data}

1989 metu visuotinio gyventoju surašymo duomenys, vol 1., Vilnius, 1991.

Brensztejn M., Spisy ludności m. Wilna za okupacji niemieckiej od d. 1 listopada 1915, Warszawa, 1919.

Czarnowski O., Metoda historyczna obliczenia liczebności ludności polskiej zamieszkałej na terytorium dawnej Litwy i Rusi pod zaborem rosyjskim, in: Pamiętnik VI Powszechnego Zjazdu Historyków Polskich w Wilnie 17-20 września 1935 r. vol. 1: Referaty, ed. F. Pohorecki, Lwów, 1935, pp. 231-238.

Czekanowski J., Stosunki narodowościowo-wyznaniowe na Litwie i Rusi w świetle źródeł oficjalnych, Lwów, 1918.

Drugi powszechny spis ludności z dn. 9 XII 1931 r. Mieszkania i gospodarstwa domowe. Ludność. Stosunki zawodowe. Miasto Wilno, Warszawa, 1937.

International migration in Lithuania. Causes, consequences, strategy, ed. A. Sipavičienè, Vilnius, 1997.

Kirkor A.H., "Ludność miasta Wilna," Teka Wileńska, 3, 1858, pp. 199-222.

Lietuvos gyventojai 2011 metais. 2011 m. gyventoju surašymo rezultatai, Vilnius, 2012.

Rocznik Statystyczny Wilna 1936, Wilno, 1938.

Spis ludności na terenach administrowanych przez zarząd Cywilny Ziem wschodnich (grudzień 1919), ed. E. Romer, Lwów, 1920.

Vilniaus miesto savivaldybès gyventojai ir būstai, Vilnius, 2004.

Вильна и окрестности. Путеводитель и историческая справочная книжка, Вильна, 1883.

Военно-статистическое обозрение Российской Империи. vol. 9, pt. 2: Виленская губерния, Санкт-Петербург, 1848.

Итоги Всесоюзной переписи населения 1970 года по Литовской СССР, Вильнюс, 1975.

Итоги Всесоюзной переписи населения 1979 года по Литовской СССР, vol. 1, Вильнюс, 1980.

Материаль для географии и статистики России, собранные офицерами Генерального штаба. Виленская губерния, еd. А. Корева, Санкт-Петербург, 1861.

Первая всеобщая перепись населения Российскй империи, 1897 г. IV. Виленская губерния, fasc. 2, Санкт-Петербург, 1901.

\section{Secondary literature}

Baliński M., Opisanie statystyczne miasta Wilna, Wilno, 1835.

Błaszczyk G., Dzieje stosunków polsko-litewskich, vol. 2: Od Krewa do Lublina, pt. 1, Poznań, 2007.

Brückner A., Starożytna Litwa. Ludy i bogi. Szkice historyczne i mitologiczne, Olsztyn, 1985.

Čaplinskas A. R., Vilniaus istorija legendos ir tikrove, Vilnius, 2010.

Cohen I., Vilna, Philadelphia, 1943.

Dohrn V., "Das Rabbinerseminar in Wilna (1847-1873). Zur Geschichte der ersten staatlichen höheren Schule für Juden im Russischen Reich," Jahrbücher für Geschichte Osteuropas, 45, 1997, pp. 379-400.

Drèma V., Dingęs Vilnius, Vilnius, 1991.

Gaučas P., Karalienė M., "Dabartines Vilniaus gyventojų nacionalines sudeties kitimo tendencijos," Geografija, 17, 1981, pp. 124-145.

Gieysztorowa I., "Państwowy spis ludności w 1789 r.," in: Pierwszy spis domów i ludności Rzeczypospolitej Polskiej 1789 r. Wybrane pisma historyczno-demograficzne, ed. M. Latuch, Warszawa, 2005, pp. 127-133. 
Hurwicz E., Der neue Osten. Waldungen und Ausichten, Berlin, 1927.

I. R., Kwestia polsko-litewska w chwili obecnej, Wilno, n.d.

Jackiewicz M., Dzieje literatury litewskiej do 1917 roku, Warszawa, 2003.

Jurkiewicz J., Rozwój polskiej myśli politycznej na Litwie i Białorusi w latach 1905-1922, Poznań, 1983.

Katalynas K., Vilniaus pletra XIV-XVII a., Vilnius, 2006.

Kazlauskaitè J., Vilniaus periodiniai leidiniai 1760-1918. Bibliografinè rodykle, Vilnius, 1988.

Kitkauskas N., Lisanka A., "Nauji duomenys apie viduramžių Vilniaus katedrą," Kultūros Barai, 1986, no. 4, pp. 59-63; 1986, no. 5, pp. 56-61; 1986, no. 6, pp. 47-51; 1986, no. 7, pp. 58-61.

Kitkauskas N., Lisanka A., "Perkūno šventyklos liekanos Vilniaus Žemutinèje pilyje," Kultūros Barai, 1986, no. 12, pp. 51-55.

Kitkauskas N., Lisanka A., Lasavickas S., "Perkūno šventyklos liekanos Vilniaus Žemutinèje pilyje," Kultūros Barai, 1987, no. 1, pp. 40-63; 1987, no. 2, pp. 53-57.

Kowalski M., "Wileńszczyzna jako problem geopolityczny w XX wieku," in: Problematyka geopolityczna ziem polskich, ed. P. Eberhardt, Warszawa, 2008, pp. 267-296.

Liedke M., Od prawosławia do katolicyzmu. Ruscy możni i szlachta Wielkiego Księstwa Litewskiego wobec wyznań reformacyjnych, Białystok, 2004.

Łossowski P., "Dwie drogi odrodzenia kulturalnego i narodowego Litwinów: Baranauskas i Basanavičius," Studia z Dziejów Rosji i Europy Srodkowo-Wschodniej, 31, 1996, pp. 149-155.

Łowmiańska M., Wilno przed najazdem moskiewskim 1655 roku, Wilno, 1929.

Łowmiański H., Studia nad dziejami Wielkiego Księstwa Litewskiego, Poznań, 1983.

Makowski B., Litwini w Polsce 1920-1939, Warszawa, 1986.

Malec J., "Charakterystyka prawnoustrojowa unii polsko-litewskiej w latach 1569-1795," in: O nowy kształt Europy: XX-wieczne koncepcje federalistyczne $w$ Europie Środkowo-Wschodniej i ich implikacje dla dyskusji o przyszłości Europy, ed. J. Kłoczowski, S. Łukasiewicz, Lublin, 2003, pp. 19-35.

Meilus E., "The history of Vilnius old Jewish cemetery at Šnipiškès in the period of the Grand Duchy of Lithuania," Lithuanian Historical Studies, 12, 2007, p. 65.

Mościcki H., Wilno, Warszawa, 1922.

Niedźwiedź J., Kultura literacka Wilna (1323-1655), Kraków, 2012.

Ostrówka M., "Polszczyzna w Wielkim Księstwie Litewskim. Aspekt arealny i historyczny," in: Kultura i języki Wielkiego Księstwa Litewskiego, ed. M.T. Lizisowa, Kraków, 2005, pp. 103-116.

Otrębski J., Gramatyka języka litewskiego, vol 1: Wiadomości wstępne. Nauka o głoskach, Warszawa, 1958.

Papée F., Aleksander Jagiellończyk, Kraków, 1999.

Radziukiewicz A., Na wschód od zachodu, Białystok, 2008.

Ragauskas A., Vilniaus miesto valdantysis elitas. XVII a. antroje pusèje (1662-1702 m.), Vilnius, 2002.

Rondomański A., Litewska krew, Wilno, 1921.

Schiper I., “Żydzi na kresach północnych i wschodnich w czasach porozbiorowych," in: $\dot{Z} y d z i$ w Polsce odrodzonej. Działalność społeczna, gospodarcza, oświatowa i kulturalna, ed. I. Schiper, A. Tartakower, A. Hafftka, Warszawa, n.d., pp. 563-574.

Semkowicz W., "Hanul, namiestnik wileński (1382-1387) i jego ród," Ateneum Wileńskie, 1-2, 1930, pp. 1-20.

Srebrakowski A., Polacy w Litewskiej SRR 1944-1989, Toruń, 2001.

Stoberski Z., Historia literatury litewskiej. Zarys, Wrocław-Warszawa-Kraków-Gdańsk-Łódź, 1986.

Sukiennicki W., “Polityczne konsekwencje błędu semantycznego," Zeszyty Historyczne, 72, 1985, pp. 18-33. 
Šalis ta Lietuva ... 1000 svarbiausiu šalies istorijos akimirkų. Žmonès, j̣vykiai, simboliai, tradicijos, ed. O. Pečiulienè, Vilnius, 2009.

Tęgowski J., Pierwsze pokolenie Giedyminowiczów, Poznań-Wrocław, 1999.

Topolska M. B., Społeczeństwo i kultura w Wielkim księstwie Litewskim od XV do XVIII wieku,

Poznań-Zielona Góra, 2002.

Всеобщій географическій и статистическій карманный атласъ, Санкт-Петербург, 1908. Гудавичюс Э., История Литвы с древнейших времен до 1569 года, vol. 1, Москва, 2005.

Саганович Г., "Вильна в описании немецкого путешественника Самуэля Кихеля (1586

г.)," in: Senosios raštijos ir tautosakos squveika: kultūrine Lietuvos Didžiosios Kunigaikštystès patirtis, Vilnius, 1998, pp. 193-197.

\section{Newspaper articles}

“Dziennikarstwo polskie na Litwie," Kuryer Litewski, no. 1 of 1 (14) September 1905, pp. 3-4. Niedziałkowski K., "Biedne miasto. (Trochę cyfr ze statystyki Wilna)", Przegląd Wileński, no. 22-23 of 8 (21) June 1913, p. 8.

"Programma na wydawanie od 1834 roku urzędowey gazety Kuryer Litewski", Kuryer Litewski, no. 154 of 29 December 1833, p. 19.

Aleksander Srebrakowski, dr, employee at the Department of Eastern European History in the Institute of History of the University of Wrocław. His research interests include the history of Vilnius, Polish diaspora, ethnic policy of the USSR, and Polish cultural monuments in the Eastern Borderlands. He is a member of the Polish-Lithuanian Bilateral Committee on Historical and Geographical Education. His publications include: Sejm Wileński 1922 roku. Idea i jej realizacja, Wrocław, 1993; Masowe deportacje radzieckie w okresie II wojny światowej, Wrocław, 1993 (co-authored with Stanisław Ciesielski and Grzegorz Hryciuk); Polacy w Litewskiej SRR 1944-1989, Toruń, 2000; Masowe deportacje ludności w Związku Radzieckim, Toruń, 2003 (co-authored with S. Ciesielski and Grzegorz Hryciuk); My nie bracia, my sasiedzi. Polska perspektywa stosunków polsko-litewskich. Wybór tekstów i dokumentów, ed. A. Srebrakowski, Wrocław, 2013.

Submitted 10.02.2020; accepted 27.05.2020 